Marek Jeziorański*

Lublin

\title{
Relacja wychowawcza w ujęciu wybranych koncepcji antropologicznych
}

Relacja wychowawcza rozumiana jest jako „zdarzenie zachodzące w konkretnym miejscu i czasie, między konkretnymi jednostkami, według pewnej strategii działania"”. Jako taka może być rozpatrywana zarówno od strony statycznej, jak i dynamicznej. Pierwsze ujęcie będzie koncentrowało się na analizie struktury relacji wychowawczej. Często ukazywana jest ona za pomocą modelu trójkąta, gdzie poszczególne jego wierzchołki wskazują na: „wychowanka”, „wychowawcę” oraz „sytuację wychowawczą"3. Drugie ujęcie - dynamiczne - związane jest z uwarunkowaniami miejsca, czasu oraz konkretnych osób. To sprawia, że każda relacja wychowawcza jest wyjątkowa i niepowtarzalna ${ }^{4}$.

Powyższe rozumienie „relacji wychowawczej” jest bliskie rozumieniu samego „wychowania”. W nim również wskazuje się na takie elementy, jak: „wychowanek”, „wychowawca” oraz „sytuacja wychowawcza”. Z tego też względu można byłoby w tym przypadku mówić o szerokim rozumieniu

* Ks. dr Marek Jeziorański jest asystentem w Katedrze Pedagogiki Ogólnej w Instytucie Pedagogiki Katolickiego Uniwersytetu Lubelskiego Jana Pawła II. Adres: Instytut Pedagogiki KUL, ul. Droga Męczenników Majdanka 70, 20-325 Lublin; e-mail: marek.jezioranski2001@ gmail.com.

${ }^{1}$ Por. Marian Nowak, Podstawy pedagogiki otwartej (Lublin: RW KUL, 1999), 156.

3 Por. tamże, 433.

4 Por. tamże, 157. 
„relacji wychowawczej”. W niniejszym artykule podjęte zostanie zagadnienie „relacji wychowawczej” w znaczeniu węższym. Byłaby ona ujmowana jedynie w kategorii elementu międzypodmiotowego, umiejscowionego pomiędzy wychowankiem a wychowawcą. Takie podejście skłania przede wszystkim do tego, by rozpoznać istotę „relacji” jako takiej, by następnie dookreślić, czym w takim ujęciu byłaby „relacja wychowawcza”.

Pierwszym pedagogiem, który w relacji wychowawczej widział specyfikę samej pedagogiki, był Herman Nohl (1879-1960), uczeń Wilhelma Diltheya (1833-1911). W swoich analizach poświęcił on „relacji wychowawczej” szczególne znaczenie. Opisywał on ją (pädagogischer Bezug) w następujący sposób: „Podstawą wychowania jest uczuciowa/pożądliwa/ emocjonalnie zaangażowana relacja (leidenschaftliches Verhältnis) dojrzałego człowieka do stającego się człowieka (zum werdenden Menschen) i to ze względu na niego samego, tak aby on doszedł do swego życia i swojej formy"s.

Wychodząc z powyższych stwierdzeń, należy przede wszystkim odpowiedzieć na pytanie, czym jest „relacja wychowawcza” w sensie wąskim, aby następnie określić, w jaki sposób jest ona uwarunkowana założeniami antropologicznymi. Takie ujęcie wynika z już przeprowadzonych poszukiwań w obszarze literatury. Problem badawczy tego artykułu sprowadza się do pytania dotyczącego tego, jak kształtuje się rozumienie/opis/definicja „relacji wychowawczej” przy różnych koncepcjach antropologicznych. Aby odpowiedzieć na to pytanie, należy przede wszystkim odpowiedzieć na pytanie, czym jest „relacja” w ogóle. To będzie stanowiło pierwszą część tego artykułu.

Następnie ukazana zostanie siatka zagadnień problemowych warunkujących rozumienie „relacji”, a w ostatniej części przedstawione zostaną wybrane koncepcje antropologiczne i ich reperkusje dla rozumienia „relacji wychowawczej”. Będą one miały ogólny charakter, pokazujący podstawowe konsekwencje przyjętych założeń antropologicznych dla znaczenia relacji między wychowawcą a wychowankiem. W ten sposób mogą stać się zaproszeniem do dalszych prac badawczych, precyzujących już poszczególne obszary pokazanej w ostatniej części tego artykułu mapy problemowej. Z tego względu uważam, że pokazanie tego pierwszego etapu - choć może on wydawać się bardzo szeroki tematycznie oraz pozostający na dość znacznym poziomie ogólności - jest ważne i potrzebne.

5 Herman Nohl, Die pädagogische Bewegung in Deutschland und ihre Theorie (Frankfurt/M., 1935), 169. 


\section{Rozumienie terminu „relacja”}

„Relacja” jako termin naukowy ma wielowiekową tradycję. Został on wprowadzony do języka naukowego już przez Arystotelesa ${ }^{6}$. Greckie pros ti zostało oddane przed łacińskie relatio, które pochodzi od referre - odnosić. Relacja zatem to „przyporządkowanie czegokolwiek czemukolwiek”7. Jest to bardzo ogólna i podstawowa definicja, na podstawie której specyfika badawcza poszczególnych nauk (np. socjologii czy psychologii) precyzuje poszczególne jej znaczenia w odniesieniu do prowadzonych przez siebie badań. W tym momencie nie chciałbym ukazywać i wyliczać tych egzemplifikacji. Pozostając przy bardzo ogólnym - filozoficznym ujęciu, można sprecyzować, że „relacja” to „odniesienie, którego następstwem jest sposób bytowania pomiędzy dwoma kresami"". To stwierdzenie wnosi do podjętych rozważań bardzo ważne spostrzeżenie dotyczące tego, że relacja jest bytem, a zatem pewną odrębną formą istnienia, oraz to, że ten byt uwarunkowany jest jego korelatami. W kontekście relacji wychowawczej tymi korelatami będą zarówno wychowawca, jak i wychowanek, którzy także są odrębnymi bytami. Idąc tym tokiem myślenia, można w tym momencie pytać o związek wymienionych bytów ze sobą, by tym bardziej poznać istotę samej relacji.

W filozofii klasycznej jest mowa o czterech najogólniejszych sposobach bytowania. Pierwsza, najwyższą formą bytu jest esse in se et per se, to jest byt w sobie. To inaczej Absolut, który jest bytem nie tylko w sobie, ale i przez/ dzięki sobie. On nie potrzebuje żadnego innego bytu do własnego istnienia. Jego istotą jest istnienie. Drugą, niższą formą bytowania jest esse in se. To substancje mające swoją podmiotowość. Jeszcze niższą formą bytowania są cechy i właściwości poszczególnych podmiotów (esse in alio). Te byty są o tyle bytami (o tyle istnieja), o ile są zapodmiotowane w bytach wyższego rzędu. Najniższą formą istnienia są relacje (esse ad aliud), gdyż istotą ich bytowania jest „być do" . Oznacza to, że specyfika ich istnienia za każdym razem uwarunkowana jest specyfiką bytów „krańcowych”. W konsekwencji

${ }^{6}$ Por. Urszula Ostrowska, „Relacje interpersonalne w edukacji”, w: Encyklopedia pedagogiczna XXI wieku, red. Tadeusz Pilch, t. V (Warszawa: Wydawnictwo Akademickie „Żak”, 2006), 183.

7 Mieczysław Albert Krapiec, „Relacja”, w: Powszechna encyklopedia filozofii, red. Andrzej Maryniarczyk i in., t. 8 (Lublin: Polskie Towarzystwo Tomasza z Akwinu, 2007), 712.

${ }^{8}$ Tamże.

9 Por. tamże, 715. 
wskazuje to, że o relacji jako takiej nie można powiedzieć więcej jak tylko tyle, że jest „łącznikiem” między dwoma bytami, a jeśli już chce się poznać i opisać specyfikę konkretnej relacji bądź jakiejś grupy relacji, to bezwzględnie należy odnieść się do istoty jej korelatów. To zagadnienie będzie ukazane w następnej części.

\section{Uwarunkowania definicyjne „relacji wychowawczej”}

Powyżej stwierdzono, że relacja jest najsłabszą formą bytu, ponieważ jej istnienie uwarunkowane jest sposobem istnienia bytów, między którymi ona ma miejsce (esse ad aliud). Głównym zagadnieniem tego artykułu jest „relacja wychowawcza”, o której H. Nohl stwierdza, że ma miejsce pomiędzy dojrzałym człowiekiem a stającym się człowiekiem.

Przyjmując te dwa założenia, należy stwierdzić, że bliższe opisanie „relacji wychowawczej" wymaga przede wszystkim wyjścia od przedstawienia (zdefiniowania) wychowawcy i wychowanka, czyli podmiotów wychowania. Na najbardziej ogólnym poziomie definiowania można powiedzieć, że tym podmiotem (z obu stron) jest człowiek. To bardzo oczywiste stwierdzenie, niemniej jednak w tym momencie potrzebne dla ukazania poszczególnych kroków analizy badanego zjawiska. Wynika z niego bowiem, że pierwszym i podstawowym obszarem warunkującym rozumienie „relacji wychowawczej” jest antropologia filozoficzna. Od przyjmowanej koncepcji osoby ludzkiej zależeć będzie istota relacji wychowawczej. Nie bez znaczenia jest zatem to, czy człowiek rozumiany jest jako platoński byt duchowy, czy jako arystotelesowski animal sociale, czy też jedynie w kategoriach materii (marksizm), bądź też jako osoba (personalizm). To jedynie kilka przykładów ukazujących różnorodne rozumienie człowieka. W tym miejscu można by było zaprezentować koncepcje antropologiczne poszczególnych filozofów ${ }^{10}$. Nie tego jednak dotyczą analizy podejmowane w tym artykule, głównym wnioskiem stąd wynikającym jest ukazanie pierwszej grupy zagadnień warunkujących rozumienie „relacji wychowawczej”, to jest koncepcji antropologicznych.

Dalsze poszukiwania skłaniają do pytania o rolę, jaką owe korelaty przyjmują w „relacji wychowawczej”. Jest to z jednej strony rola wychowawcy, a z drugiej strony rola wychowanka. Tym, co warunkuje właściwe

10 Jedną z ostatnio wydanych książek w tym temacie jest: Marek Drwięga, Kim jest człowiek? Studia z filozofii człowieka (Kraków: Księgarnia Akademicka, 2013). 
wypełnianie tych ról, jest zarówno przyjmowana teoria wychowania, jak i oczekiwania społeczne. Oznacza to, że drugim obszarem czynników warunkujących rozumienie „relacji wychowawczej” będą założenia wynikające z wyboru koncepcji bądź teorii wychowania. W tym momencie, chcąc ukazać całość problematyki, należy się odnieść do dostępnych koncepcji systematyzujących teorie wychowania. I tak na przykład Herbert Gudjons wskazuje na trzy główne teorie wychowania: teoria humanistyczna (podejmująca tradycje W. Diltheya), teoria krytyczno-racjonalna (pedagogika empiryczna) oraz teoria krytyczna. Poza tym wskazuje on również na pomniejsze teorie, do których zalicza: pedagogikę transcendentalną (normatywną), historyczno-materialistyczną, fenomenologiczną, teoretyczno-systemową oraz konstruktywistyczną ${ }^{11}$. Podobnie przedstawia to zagadnienie inny współczesny niemiecki badacz - Heinz Hermann Krüger, który również prezentuje siatkę teoretycznych ujęć wychowania w dwóch grupach - głównych i innych kierunków wychowania. Różnice dotyczą jedynie prezentacji drugorzędnych kierunków. Zalicza do nich: pedagogikę prakseologiczną, transcendentalną, historyczno-materialistyczną, psychoanalityczną, fenomenologiczną, feministyczną i systemową. Poza tym wskazuje jeszcze na podejście strukturalistyczne, ujęcie ekologiczne oraz postmodernizm w pedagogice ${ }^{12}$.

Inną propozycją całościowego ujęcia teorii pedagogicznych jest systematyzacja amerykańskiego filozofa wychowania Geralda L. Gutka. Wskazuje on na pięć podstawowych teorii wychowania, do których zalicza: esencjalizm, perenializm, progresywizm, społeczny rekonstrukcjonizm oraz teorię krytyczną ${ }^{13}$. Jeszcze inną propozycją może być ujęcie ks. Mariana Nowaka ${ }^{14}$ czy też cały czas podejmowane prace nad tym zagadnieniem Bogdana Śliwerskiego ${ }^{15}$.

W tym momencie również - jak powyżej - nie tyle chodzi o to, by dać pełny obraz współczesnych teorii i koncepcji wychowania, co raczej o to, by prezentując ich różnorodność, ukazać przez to różnorodność drugiej grupy

${ }^{11}$ Por. Herbert Gudjons, Pädagogisches Grundwissen (Bad Heilbrunn: Klinkhardt, 2012), $30-52$.

12 Por. Heinz-Hermann Krüger, Metody badań w pedagogice (Gdańsk: GWP, 2007), $11-13,70-139$.

${ }_{13}$ Por. Gerald L. Gutek, Filozofia dla pedagogów (Gdańsk: GWP, 2007), 265-337.

14 Por. Marian Nowak, Teorie i koncepcje wychowania (Warszawa: Wydawnictwo Akademickie i Profesjonalne, 2008), 232-286.

15 Por. Pedagogika. Podręcznik akademicki, red. Zbigniew Kwieciński, Bogusław Śliwerski, t. 1. (Warszawa: Wydawnictwo Naukowe PWN, 2005), 184-467; Bogusław Śliwerski, Współczesne teorie i nurty wychowania (Kraków: Impuls, 2010). 
czynników warunkujących rozumienie „relacji wychowawczej”. Należy jednak od razu zaznaczyć, że oba wskazane obszary czynników nie są równoważne. Zdecydowanie podstawowe znaczenie mają rozstrzygnięcia dotyczące filozofii człowieka ${ }^{16}$, gdyż te są również fundamentem dla poszczególnych teorii wychowania, bez względu na to, czy ich twórcy odnoszą się do nich wprost czy też nie. Francuski filozof Lucien Laberthonnière (1860-1932) stwierdził, że: „koncepcja wychowania i zadań stojących przed wychowawcą jest pochodną koncepcji człowieka i jego przeznaczenia""17.

Ostatnim elementem analizy relacji w tej części będzie przedstawienie jej specyfiki w odniesieniu do różnorodności rodzajów podmiotów, między którymi ona ma miejsce. Wyróżnić można zatem następujące cztery jej rodzaje $^{18}$ :

1. Człowiek w relacji do samego siebie. Jest to relacja intrapersonalna. Szczególne znaczenie tej relacji nadaje interakcjonizm symboliczny reprezentowany przez amerykańskiego badacza Georga Meada (1863-1931). W swej teorii ontycznej jaźni rozróżnia on element $I$ - kojarzony z indywidualnymi cechami osoby oraz element $m e$ - który odpowiada pewnego rodzaju instancji grupy odniesienia lub osoby znaczącej ${ }^{19}$. W kontekście wychowania relacje intrapersonalne mogłyby być kojarzone z procesem samowychowania.

2. Człowiek w relacji do drugiego człowieka. Jest to jedna z najbardziej pierwotnych i powszechnych relacji - relacja interpersonalna. $\mathrm{W}$ pedagogice stoi ona u początku praktyki wychowawczej i naukowej refleksji nad wychowaniem. Już sam źródłosłów słowa - pajdagogos wskazuje na osobę tego, który prowadzi i tego, który jest prowadzony ${ }^{20}$. Wśród zmieniających się koncepcji wychowawczych zmieniała się również strategia „ważności” czy dominacji, w tym układzie osoby wychowawcy bądź wychowanka, niemniej jednak jako kluczowe pozostało to, że relacja wychowawcza jest relacją o układzie dwuosobowym.

16 Termin „,filozofia człowieka” oraz ,antropologia” rozumiem synonimicznie, zgodnie z: Drwięga, Kim, 24.

${ }^{17}$ Lucien Laberthonnière, Théorie de l'éducation (Paris, 1901), 3; za: Nowak, Podstawy, 312.

18 Por. Ostrowska, „Relacje”, 179.

19 Por. Krüger, Metody, 63.

${ }^{20}$ Por. Stanisław Kot, Historia wychowania, t. 1 (Warszawa: Wydawnictwo Akademickie „Żak”, 2010), 57. 
3. Człowiek w relacji do zborowości. Jednym z pierwszych określeń człowieka w historii filozofii jest arystotelesowskie: politikon dzoon - człowiek istotą społeczną ${ }^{21}$. Stanisław Kot stwierdza natomiast, że „człowiek kryje w sobie dwie natury. Każda jednostka jako istota biologiczna, o indywidualnym rozwoju psychofizycznym, przeżywa stany czysto osobiste i zdarzenia indywidualnej egzystencji [...]. Ale dzięki posiadaniu instynktu społecznego, wspartego umiejętnością mowy, człowiek rozwinął życie zbiorowe"22. Na podstawie przytoczonych wypowiedzi nie można również pominąć tego elementu w analizie relacji wychowawczej. Będzie on dotyczył przede wszystkim społecznego kontekstu rozwoju osoby. Inaczej mówiąc, można tu wskazać dwie odmiany relacji: człowiek-zbiorowość w kontekście wychowawczym. Po pierwsze można mówić o sytuacji, w której indywidualny wychowawca jest $\mathrm{w}$ relacji do zbiorowości wychowanków, lub - w sytuacji odwróconej-gdy wychowawca jest podmiotem zbiorowym względem jednostki.

4. Zbiorowość w relacji do innej zbiorowości. W tym układzie zatraca się indywidualny człowiek i można byłoby powiedzieć, że z tego właśnie względu nie może taka sytuacja mieć swojego odpowiednika z relacji wychowawczej. W obszar nauk o wychowaniu taki paradygmat został przeniesiony przez teorię systemową z jej głównym reprezentantem - niemieckim socjologiem Niklasem Luhmannem (1927-1998) oraz przez teorię strukturalizmu społecznego Claude'a Lévi-Straussa (1908-2009). W tych ujęciach podkreśla się, że jednostka jest częścią szerszej struktury i to właśnie zmiany wywołane w niej powodują konsekwentnie zmiany w sposobie myślenia i działania jednostki. Francuski socjolog mówił: „Nie pretendujemy [...] do pokazania, jak ludzie myślą w mitach, lecz do tego, aby pokazać, jak mity są myślane w ludziach bez ich wiedzy" ${ }^{\prime 23}$.

W powyższej części artykułu starano się ukazać uwarunkowania definicyjne relacji wychowawczej, to znaczy te zagadnienia, które należy wziąć pod uwage przy definiowaniu tego zjawiska. Wskazano na trzy grupy zagadnień. Po pierwsze: koncepcja antropologiczna, po drugie: koncepcja wychowania, po trzecie: jednostkowy bądź zbiorowy podmiot wychowania.

${ }^{21}$ Por. Arystoteles, Polityka (Warszawa: PWN, 2010), 27 (1.1.10 - wg numeracji ksiąg, rozdziałów i paragrafów).

${ }^{22}$ Kot, Historia, 13.

${ }^{23}$ Claude Lévi-Strauss, Mythologiques, t. 1: Lec cru et le ciut (Paris, 1964), 20 - za: Jerzy Szacki, Historia myśli socjologicznej (Warszawa: Wydawnictwo Naukowe PWN, 2012), 689. 
Spośród tych czynników decydujące znaczenie ma teoria człowieka. Dwa pozostałe, choć mają bezpośredni wpływ na rozumienie samej „relacji wychowawczej”, są także warunkowane założeniami antropologicznymi.

\section{Rozumienie „relacji wychowawczej” w kontekście wybranych ujęć antropologicznych}

W tej części artykułu ukazane zostaną wybrane koncepcje antropologiczne i ich znaczenie dla rozumienia ,relacji wychowawczej”. Nie jest to oczywiście zbiór zamknięty. Ma on jedynie zasygnalizować problem i zachęcić do dalszych poszukiwań. Można powiedzieć, że każda koncepcja antropologiczna skutkuje odmiennym rozumieniem „relacji wychowawczej”. To skłaniałoby do przeanalizowania dzieł poszczególnych filozofów. Można również podejść do badanego zagadnienia od strony kierunków antropologicznych. Takie rozwiązanie ograniczyłoby nadmiar stanowisk w odniesieniu do „relacji wychowawczej”, ale mogłoby zatracić niuanse różniące poszczególne podejścia. Poza tym współczesna literatura filozoficzna nie ukazuje zbyt wielu syntezujących i klasyfikujących ujęć antropologicznych. Do tego typu przykładów można zaliczyć Ja-człowiek Mieczysława Alberta $\mathrm{Krapca}^{24}$. Na gruncie pedagogiki warto wspomnieć tu o takich dziełach, jak: Wartości. Człowiek. Wychowanie ${ }^{25}$ oraz Antropologiczna pedagogika ogólna ${ }^{26}$.

Mieczysław A. Krapiec ukazuje dwie główne grupy stanowisk antropologicznych: 1) koncepcje człowieka jako tworu natury oraz 2) koncepcje człowieka jako podmiotu ujawniającego ducha. W pierwszej grupie podkreśla się ważność nauk przyrodniczych a człowiek jest „wyjaśniany ostatecznie przez odwołanie się do praw przyrody i jej rozwoju" "27. W tym kontekście wymieniane są następujące ujęcia antropologiczne: a) interpretacja biologiczno-ewolucyjna, b) marksistowska koncepcja człowieka, c) psychoanalityczna interpretacja człowieka oraz d) koncepcja człowieka w kontekście strukturalizmu.

${ }^{24}$ Mieczysław Albert Krapiec, Ja-człowiek (Lublin: Wydawnictwo KUL, 2005).

${ }^{25}$ Władysław Cichoń, Wartości. Człowiek. Wychowanie (Kraków: Wydawnictwo Uniwersytetu Jagiellońskiego, 1996).

${ }^{26}$ Antropologiczna pedagogika ogólna, red. Marian Nowak, Piotr Magier, Iwona Szewczak (Lublin: Gaudium, 2010).

${ }^{27}$ Krapiec, Ja-człowiek, 67. 
Druga grupa koncepcji antropologicznych akcentuje przede wszystkim te elementy, które sprawiają że człowiek transcenduje świat przyrody. Choć do niego należy, to, co stanowi istotę człowieka, nie jest uwarunkowane biologicznie. W tej grupie wymieniane są następujące podejścia: a) kartezjańska antropologia, b) egzystencjalistyczna koncepcja człowieka oraz c) wizja człowieka Maxa Schelera.

Poza wymienionymi dwoma grupami ujęć antropologicznych M. A. Krąpiec wskazuje również na rozumienie człowieka w kontekście klasycznej (realistycznej) filozofii bytu. Wyraża on zarazem stanowisko, zaprezentowanie już wcześniej przez Stanisława Kamińskiego, że jedynie tak rozumiana filozofia człowieka ,jest najwszechstronniej uprawomocniona; najadekwatniej może spełnić wysuwane pod jej adresem postulaty światopoglądowe i funkcje usługowe dla dyscyplin praktycznych, a przy tym nie musi naruszać ogólnie wymaganych kryteriów dla wiedzy racjonalnej"28. Takie ujęcie antropologiczne charakteryzuje się nieredukcjonistycznym opisem człowieka, co pozwala na zaprezentowanie „faktu ludzkiego" z uwzględnieniem szerokiego spektrum badań nauk szczegółowych, filozoficznych oraz teologicznych. Dlatego też - jak twierdził M. A. Krapiec - „poza filozofią realistyczna, która jest interpretacją świata realnie istniejącego i poszukiwaniem czynników uniesprzeczniających fakty w tym świecie, pozostałe filozofie są spekulacjami apiorycznymi" 29 .

Poniżej zostaną przestawione wybrane teorie człowieka, a na ich podstawie ukazana będzie specyfika „relacji wychowawczej”. Zdaję sobie sprawę z wybiórczości prezentowanych stanowisk. Podstawowym celem tych analiz jest przede wszystkim wskazanie na wagę problemu uwzględniania założeń antropologicznych w badaniach pedagogicznych, następnie uzasadnienie tej tezy w odniesieniu do przykładowych antropologii.

\subsection{Ujęcie ewolucyjne: „Czlowiek - kosmicznym rozbójnikiem"}

Można powiedzieć, że rozumienie człowieka jako elementu świata przyrody zawsze było obecne w refleksji antropologicznej. Można tu przy-

${ }^{28}$ Stanisław Kamiński, „Z metafilozofii człowieka”, w: Krąpiec, Ja-człowiek, 12.

29 Mieczysław Albert Krąpiec, Porzucić świat absurdów (Lublin: Polskie Towarzystwo Tomasza z Akwinu, 2002), 84. 
wołać chociażby arystotelesowskie: dzoon politikon ${ }^{30}$ lub trzcina myślaca Błażeja Pascala. Jednak to stanowisko zostało bardzo radykalnie wzmocnione od czasu wydania $O$ powstawianiu gatunków Karola Darwina w 1859 roku. W tamtym czasie nastapiło szczególne zainteresowanie człowiekiem jako istotą przyrodniczą, a - w skrajnych ujęciach - jedynie jako istotą przyrodniczą. $\mathrm{W}$ tej interpretacji człowiek rozumiany jest jako najdoskonalsze stadium ewolucji. W ramach tego stanowiska można wyodrębnić ewolucjonizm przyrodniczy (czysto biologiczny) Juliana Huxleya (1887-1975) oraz ewolucjonizm kierowany Pierre'a Teilharda de Chardina (1881-1955). Ten drugi stara się łączyć elementy ewolucjonizmu biologicznego z treścią chrześcijańskiego Objawienia, ukazując zarazem Boga w kategoriach dynamicznego odniesienia do świata. Dlatego ten Bóg przestaje być Budowniczym a staje się „Poruszycielem ewolucji”. Przybiera nazwę „Boga kosmogenezy”, „Boga syntezy kosmicznej”’31. Ujęcie ewolucyjne opisuje człowieka zarówno w kategoriach wyjątkowości wobec innych istot przyrodniczych, „szczęściarza”, któremu udało się wzbić na szczyt łańcucha pokarmowego, ale i przypadkowości, ponieważ nic z sukcesu człowieka nie jest jego zasługą. Oznacza to również, że człowiek nie jest szczególną i wyjątkową istotą na świecie, ale że wpisuje się w określoną całość świata zwierząt i tak też jest opisywany ${ }^{32}$.

„Relacja wychowawcza” w tym kontekście będzie musiała być przede wszystkim opisywana w kategoriach spontaniczności i naturalności. „Podmiotem" budującym z człowiekiem tego rodzaju relację będzie przede wszystkim świat przyrodniczy. Samą „relację wychowawczą” można by w tym ujęciu nazwać „relacją przyrodniczą”, to znaczy taką, która „wydarza się" ze względu na biologiczne uwarunkowania człowieka, a nie jest podejmowana na podstawie przesłanek racjonalnych. Ewolucyjne rozumienie człowieka konsekwentnie skutkuje tym, że drugim „krańcem” tak rozumianej „relacji wychowawczej” jest przede wszystkim bezosobowy świat przyrody. On przejmuje miejsce wychowawcy. Człowiek (zarówno wychowawca, jak i wychowanek) nie kieruje tą relacją, nie jest nawet do tego zdolny, ponieważ ona wpisana jest w proces ewolucji. Poza tym przy takich założeniach

${ }^{30}$ Gdzie dzoon oznacza: istotę żywą, zwierzę. Remigiusz Popowicz, Wielki słownik grecko-polski (Warszawa: Oficyna Wydawnicza „Vocatio”, 2006), 258.

${ }^{31}$ Por. Krąiec, Ja-człowiek, 73-74.

32 Por. Winfried Marotzki, Arnd-Michael Nohl, Wolfgang Ortlepp, Einführung in die Erziehungswissenschaft (Opladen \& Farmington Hills: Verlag Barbara Budrich, 2006), 108. 
antropologicznych można mówić, że wychowanie odnosi się nie tylko do człowieka, ale również do zwierząt.

\subsection{Ujęcie biologiczne: „Człowiek - fizjologicznym wcześniakiem"}

Szczególnym rodzajem podejścia opartego na założeniach biologicznych są badania prowadzone przez Adolfa Portmanna (1897-1982), szwajcarskiego zoologa. Główna teza A. Portmanna sprowadza się do tego, że człowiek jest fizjologicznym wcześniakiem ${ }^{33}$. Oznacza to, że rozwój człowieka w porównaniu do głównego podziału zwierząt na zagniazdowniki i gniazdowniki jest procesem wyjątkowym, bo niemieszczącym się w podanej wyżej klasyfikacji. A. Portmann nazywa człowieka „niby-gniazdownikiem” bądź „wtórnym gniazdownikiem" ${ }^{34}$. Otóż po osiagnięciu stadium rozwoju prenatalnego na poziomie gniazdowników ${ }^{35} \mathrm{w}$ dalszym ciągu następuje rozwój ontogenetyczny w łonie matki. Można by się spodziewać, że ten rozwój będzie trwał do osiagnięcia przez człowieka stadium zagniazdowników, to jest takiego, które po urodzeniu i odstawieniu od pokarmu matki pozwoli mu samodzielnie funkcjonować. Według obliczeń A. Portmanna przy takim założeniu rozwój życia płodowego musiałby trwać ok. 20-21 miesięcy ${ }^{36}$. Tak się jednak nie dzieje. W trakcie tego rozwoju coś „wyrzuca” człowieka z tego procesu i sprawia, że człowiek, przychodząc na świat, skazany jest na opiekę (tak jak gniazdowniki), ale zarazem ma otwarte zmysły, co stawia go w zupełnie oryginalnej sytuacji. W tym czasie jednak (ok. jednego roku, który ,powinien” być rozwojem wewnątrzorganicznym) w człowieku kształtują się typowo ludzkie cechy: wyprostowana postawa, mowa i związana z nią sfera symboliczna oraz działanie związane ze współtworzeniem otoczenia ${ }^{37}$. W tym kontekście można powiedzieć, że środowisko zewnętrzne ma istotowe znaczenie dla pełnego rozwoju człowieka.

$\mathrm{Na}$ bazie takiej antropologii można konsekwentnie wskazać wnioski pedagogiczne dotyczące „relacji wychowawczej”. Pierwszym z nich będzie

${ }^{33}$ Por. Friedriech W. Kron, Pedagogika. Kluczowe zagadnienia (Sopot: GWP, 2012), 173.

34 Por. tamże, 174.

${ }^{35}$ Tzn. zwierząt, które po przyjściu na świat są zdane na opiekę, gdyż nie widzą ani nie słyszą.

${ }^{36}$ Por. Kron, Pedagogika, 174.

37 Por. tamże. 
stwierdzenie, że relacja pomiędzy przychodzącym na świat człowiekiem a środowiskiem społecznym jest w ogóle możliwa. Można nawet powiedzieć, że jej zaistnienie jest pozytywną odpowiedzią „,natury” na owo swoiste ,wyrzucenie" człowieka z procesu rozwojowego. To tak jakby natura sama „zrzekała” się dominującego znaczenia w kształtowaniu człowieka na rzecz społeczności ludzkiej. Nie jest to zatem „relacja przyrodnicza” jak powyżej ukazano.

Po drugie relacja wychowawcza jest bezwzględnie konieczna. Człowiek jawi się tu jako istota naznaczona brakami w porównaniu do innych ssaków. Badania w tym obszarze zapoczątkował Jakob von Uexküll (1864-1944). Wprowadzając kategorię środowiska do nauk biologicznych, stwierdził, że zwierzę postrzega je zawsze przez pryzmat określonych kodów gatunkowych. One właśnie umożliwiają mu bezbłędne poruszanie się po danym środowisku, rozpoznając w nim zarówno pożywienie, jak i zagrożenie. Człowiek przeciwnie, nie posiadając takich kodów, charakteryzuje się pełną otwartością na swoje środowisko ${ }^{38}$. To jednak z jednej strony czyni go bezbronnym (bo nie posiada instynktu przewidywania zagrożenia) i bezradnym wobec środowiska, ale z drugiej strony posiada on taką specyficzną cechę, jaką jest wyuczalność (lub szerzej: wychowalność).

\subsection{Ujęcie genetyczne: „Czlowiek - maszyną”}

Innym szczegółowym podejściem w obszarze ujęć biologiczno-ewolucyjnych jest podejście odwołujące się do coraz bardziej rozwijających się badań genetycznych. Pojedynczymi przykładami wyników takich badań, mających swoje szczególne znaczenie dla nauki o wychowaniu, mogą być na przykład hipoteza babci ${ }^{39}$ lub wyjaśnienia dotyczące altruizmu ${ }^{40}$. Ogólnie mówiąc, sprowadzają się one do próby wyjaśnienia przykładowych ludzkich

${ }^{38}$ Franz-Peter Burkard, Axel Wei $\beta$, Dtv-Atlas Pädagogik (München: Deutscher Taschenbuch Verlag GmbH \& Co. KG, 2008), 149.

${ }^{39}$ Hipoteza ta stara się wyjaśnić, dlaczego w gatunku homo sapiens istnieje istotna różnica co do krzywej płodności w porównaniu do innych ssaków oraz jakie to mogło mieć znaczenie dla rozwoju człowieka. Por. Kristen Hawkes, „Großmutter-Effekt”, w: Evolution und Kultur des Menschen, red. Ernst Peter Fischer, Klaus Wiegandt (Frankfurt a. M.: Fischer Verlag, 2010), 170-196.

${ }^{40}$ Manfred Milinski, „Egoismus schafft Gemeinsinn”, w: Evolution und Kultur des Menschen, red. Ernst Peter Fischer, Klaus Wiegandt (Frankfurt a. M.: Fischer Verlag, 2010), 270-291. 
zachowań w oparciu o strukturę genetyczną człowieka. Szerszym kontekstem takich ujęć jest rozumienie człowieka w kategoriach „Maszyny”. Bliżej tymi zagadnieniami zajmuje się Käte Meyer-Drawe (1949-), niemiecki pedagog ogólny. Dopisuje ona takie rozumienie człowieka do trzech „zniewag człowieka" wprowadzonych przez Zygmunta Freuda. Pierwszą była rewolucja kopernikańska i pozbawienie człowieka centralnego miejsca we Wszechświecie („zniewaga kosmologiczna”). Drugą była teoria Darwina („zniewaga biologiczna”), pozbawiająca człowieka szczególnego miejsca wśród istot przyrodniczych. Do kolejnej doprowadziły badania samego Freuda (,zniewaga psychoanalityczna”). Przeniosła ona punkt decyzyjności człowieka z obszaru rozumu do podświadomości. Obecną, genetyczną lub „cybernetyczną obrazą" człowieka miałoby być dalsze deprecjonowanie wyjątkowości człowieka i wpisanie go w świat rzeczy i maszyn ${ }^{41}$. Takie stanowisko znane było już w Oświeceniu za sprawą francuskiego filozofa Juliena Offreya de La Mettrie'a (1709-1751) ${ }^{42}$ i wtedy było niewątpliwie pokłosiem myśli Kartezjańskiej z tą różnicą, że La Mettrie całkowicie odrzucił element świadomościowy, stwierdzając, że człowiek to tylko res extensa. Niemniej jednak w ostatnich latach, wraz z rozwojem zarówno genetyki, jak i automatyki czy informatyki, świat człowieka oraz świat maszyn-automatów zbliżyły się do siebie. W wielu obszarach życia maszyny zastępują ludzi, przez co według niektórych te dwa światy są utożsamiane. Symbolem harmonijnej symbiozy miałaby być kategoria Cyborga (ang. Cyb - Cybernetic; Org Organism $)^{43}$.

Przedstawione podejście antropologiczne suponowałoby takie rozumienie ,relacji wychowawczej”, w której wychowanek traktowany byłby zupełnie przedmiotowo. Wychowawca przejmowałby pełną odpowiedzialność za „wykształcenie” (nie tylko w sensie intelektualnym!) człowieka. W pełni odpowiadającą metaforą takiego rozumienia ,relacji wychowawczej” byłby obraz kowala bądź rzeźbiarza, którzy z pełnym zaangażowaniem nadają formę młodemu człowiekowi. Poza tym na znaczeniu zyskałoby kształcenie funkcjonalne. Dużym zainteresowaniem cieszyłyby się poszczególne techniki, narzędzia czy metody wychowawcze służące właściwemu „zaprogramowaniu” człowieka. W skrajnych ujęciach kategorię „wychowania” nale-

${ }^{41}$ Marotzki, Nohl, Ortlepp, Einführung, 109.

42 Janusz Mączka, „La Mettrie Julien Offrey de”, w: Powszechna encyklopedia filozofii, red. Andrzej Maryniarczyk i in., t. 6 (Lublin: Polskie Towarzystwo Tomasza z Akwinu, 2005), 179.

${ }^{43}$ Marotzki, Nohl, Ortlepp, Einführung, 111. 
żałoby zastapić kategorią „,programowania”. Chodziłoby o to, by tak urobić człowieka, żeby on mógł w sposób jak najbardziej efektywny funkcjonować w przestrzeni społecznej.

Przy współczesnym rozwoju nauk genetycznych coraz śmielej wyraża się pogląd o możliwościach zmian w strukturze DNA, co może się kojarzyć z „wychowaniem na skróty”, gdzie wysiłek pracy wychowawczej zostałby zastapiony ingerencją w ,oprogramowanie” człowieka. Antropologia „Człowieka-Maszyny” nie widzi w tym zagrożenia, gdyż takie działania dotyczą tylko ciała, które widziane jest jedynie w kategoriach maszyny.

\subsection{Ujęcie marksistowskie: „Czlowiek - wytworem spolecznym"}

Specyfiką tego podejścia jest akcentowanie społecznych uwarunkowań rozwoju jednostki. Poza świadomością oraz pracą to jeden z trzech głównych elementów struktury ontycznej człowieka. Według Karola Marksa (1818-1883) człowiek jest „,całokształtem stosunków społecznych”"44. Niemniej jednak nie wszystkie relacje społeczne służą prawidłowemu rozwojowi osób. Analizowane przez K. Marksa układy społeczne doprowadziły go do wniosku, że człowiek stał się „sługą i niewolnikiem tych stosunków”45, które z kolei doprowadzily do jego wyalienowania. W tym procesie szczególne znaczenie miały stosunki poniżające i ujarzmiające człowieka.

Odnosząc te zagadnienia do relacji wychowawczej, należy przede wszystkim zauważyć, że człowiek jest skazany na relację z otaczającym go środowiskiem społecznym. To właśnie dzięki tym odniesieniom człowiek staje się tym, kim się staje. Sam z siebie nie ma natomiast żadnej treści, jest tabula rasa. A zatem należały mówić o konieczności relacji wychowawczej. W tym przypadku nie jest to jednak relacja czysto przyrodnicza, lecz przede wszystkim społeczna. To znaczy, że czynnik racjonalny, wyrażający się poprzez określoną możliwość decyzyjną człowieka, jest w niej obecny. To ważne, ponieważ w kontekście marksistowskiej koncepcji antropologicznej należy przede wszystkim zadbać o to, by relacja wychowawcza była wolna od jakichkolwiek elementów zniewalających czy poniżających wychowanka. Zasadniczą cechą wychowawcy (a w procesie samowychowania - wychowanka) będzie podejrzliwość! Chodzi o zachowawcze nastawienie do

\footnotetext{
${ }^{44}$ Tamże, 78-79.

45 Tamże, 77.
} 
tradycji, religii, struktur władzy i ustroju społecznego, które dążą do uprzedmiotowienia człowieka.

\subsection{Ujęcie psychoanalityczne: „Człowiek - «polem» walki nieosobowych sil"}

Twórcą tej koncepcji jest Zygmunt Freud (1856-1939). Bogdan Suchodolski pisał o nim, że zmierzał on do:

stworzenia teorii, która by wyjaśniała całego człowieka, wszystkie jego przeżycia i różnorakie kierunki całej jego działalności. Można sądzić, iż Freud był ostatnim psychologiem realizującym wielkie powołanie psychologii jako nauki o człowieku; można jednak sądzić, iż był on pierwszym nowoczesnym psychologiem, który rozumiał, iż ludziom współczesnym potrzebna jest przede wszystkim nowa nauka o człowieku, wielka filozoficzna antropologia ${ }^{46}$.

Ta antropologia sprowadza się przede wszystkim do zasady bezwzględnej determinacji zjawisk psychicznych. Oznacza to, że każde zjawisko psychiczne jest zdeterminowane jedną lub wieloma przyczynami o charakterze nieświadomym ${ }^{47}$. Szczególne znaczenie $\mathrm{w}$ tym kontekście mają czynniki biologiczno-seksualne, które traktowane są jako podstawowe determinanty, dzięki którym tłumaczy się całe życie człowieka ${ }^{48}$. W takim ujęciu człowiek traci swoją podmiotowość, gdyż staje się jedynie „polem” „walki i spiętrzenia się sił nieosobowych"49.

Ważnym uzupełnieniem psychoanalitycznej koncepcji jest zagadnienie struktury człowieka. Według Freuda człowiek składa się z trzech poziomów: Id, Ego i Superego. Poziomem centralnym jest jaźń, czyli Ego - to obszar ludzkiej świadomości. Jest ona jednak zdeterminowana wpływami Id oraz Superego. Te pierwsze sprowadzają się do uwarunkowań wynikających z natury. Zaliczyć do nich należy popędy i instynkty, szczególnie libido oraz thanatos. Uwarunkowania Superego natomiast wynikaja z kontekstu społecznego.

46 Bogdan Suchodolski, „Wstęp”, w: Zygmunt Freud, Człowiek - religia - kultura (Warszawa: Książka i Wiedza, 1967), 13-14.

${ }^{47}$ Por. Krąpiec, Ja-człowiek, 80.

48 Por. tamże, 81.

49 Tamże, 87. 
Przenosząc te zagadnienia do kontekstu relacji wychowawczej, trzeba przede wszystkim stwierdzić, że skoro „człowiek ukazuje się zlepkiem, dość przypadkowym, sił nieosobowych" ${ }^{50}$, to relacja wychowawcza będzie miała bardziej charakter przedmiotowy. Wychowanek (w sensie Ego) nie może być traktowany jako partner tej relacji. Wychowawca będzie bardziej koncentrował się na tych dwóch płaszczyznach osobowych, które odpowiedzialne są za rozwój człowieka, to jest Id i Superego. To z kolei oznacza, że relacja wychowawcza będzie zawsze zapośredniczona i będzie można ją ukazać w schemacie: wychowawca - Id - wychowanek lub też: wychowawca - Superego - wychowanek.

Dążenia wynikające $\mathrm{z}$ tych dwóch obszarów są wprawdzie względem siebie przeciwstawne, ale zarówno jedne, jak i drugie zmierzają do coraz pełniejszego zawładnięcia sferą Ego. Treścią relacji wychowawczej będzie szukanie takiego poziomu równowagi między Id a Superego, by dokonywał się wzrost Ego - obszaru świadomości wychowanka. Działania wychowawcy będą polegały na takim rozpoznawaniu oraz wzmacnianiu lub wygaszaniu sfer Id i Superego, by odpowiednio nie dopuścić do dominacji jednej z nich. Należy bowiem zaznaczyć, że dominacja Id będzie skutkowała liberalnym stylem wychowania, a dominacja Superego - autorytarnym stylem ${ }^{51}$.

\subsection{Ujęcie fenomenologiczne: „Człowiek - tworzący samego siebie"}

Inspirująca propozycją $\mathrm{w}$ podejmowanych rozważaniach jest antropologia Karola Wojtyły (1920-2005). Profesor KUL, a następnie papież Jan Paweł II, w swoich filozoficznych dociekaniach posługiwał się metodą fenomenologiczną. Każe ona koncentrować się badaczowi na samych faktach, aby następnie określać związek między poszczególnymi faktami, ich specyfikę czy też wspólne cechy. K. Wojtyła, wyjaśniając swoje podejście metodologiczne, prowokacyjnie pyta: ,czy nasze poznanie tego, kto działa, nie kształtuje się w zasadniczej mierze poprzez doświadczenie i zrozumienie tego «że» - i tego «jak» działa ów działający podmiot?" 52 .

50 Tamże.

${ }^{51}$ Por. Marian Nowak, Pedagogiczny profil nauk o wychowaniu. Studium z odniesieniami do pedagogiki pielęgniarstwa (Lublin: Wydawnictwo KUL, 2012), 337.

52 Karol Wojtyła, „Teorie - praxis: temat ogólnoludzki i chrześcijański”, w: Karol Wojtyła, 
Wyżej opisaną metodą K. Wojtyła posługuje się, prezentując swoją teorię człowieka w studium Osoba i czyn ${ }^{53}$. Ukazuje tam, że twórcą człowieka jest przede wszystkim on sam: „twórczość, dla której pierwszym tworzywem jest sam człowiek. Człowiek przez działanie kształtuje przede wszystkim samego siebie" ${ }^{54}$. Podejmując to zagadnienie w sposób bardzo obszerny i drobiazgowy, K. Wojtyła dochodzi do przekonania, że w człowieku można wyróżnić dwa rodzaje pragnień czy inspiracji. Określa je jako: ,ja chcę” oraz „chce mi się” i wyjaśnia:

Notabene do istoty przeżycia ,ja chcę”, do istoty woli, należy to, że przeżycie owo nigdy nie występuje w człowieku jako ,dzianie się”, ale zawsze jako „działanie" 55 - i to jako sam rdzeń każdego działania. Osoba jako osoba jest wówczas czynna. Owe chcenia, które nie tkwią w samostanowieniu, są tym niemniej - wedle terminologii stosowanej przez fenomenologów - aktami intencjonalnymi. Stwierdzamy w nich skierowanie do jakiejś wartości jako do celu, i to czasem skierowanie bardzo intensywne w przeżyciu; wówczas szczególnie uwydatnia się np. ich charakter pożądawczy. A jednak to wszystko nie wystarcza do stwierdzenia woli. Język nasz w swej wielkiej precyzji odróżnia dokładnie przeżycie ,ja chcę” od przeżycia „chce mi się”. W jednym i drugim zachodzi chcenie. A przecież tylko to pierwsze zawiera w sobie prawdziwą dynamikę woli ${ }^{56}$.

Zakładając taką koncepcję antropologiczną, przyjmuje się, że relacja wychowawcza, służąca rozwojowi osobowemu, będzie w procesie przebiegała pomiędzy dwoma punktami w strukturze osobowej człowieka, a mianowicie pomiędzy ,ja chcę” i „chce mi się”. Oznacza to zatem, że zarówno jednym, jak i drugim korelatem wskazanej wyżej relacji wychowawczej bę-

Osoba i czyn i inne studia antropologiczne, red. Tadeusz Styczeń i in. (Lublin: Towarzystwo Naukowe KUL, 2011), 468.

${ }^{53}$ Karol Wojtyła, „Osoba i czyn”, w: Karol Wojtyła, Osoba i czyn oraz inne studia antropologiczne, red. Tadeusz Styczeń i in. (Lublin: Towarzystwo Naukowe KUL, 2011), 43-344.

${ }^{54}$ Tamże, 120.

55 To również rozróżnienie, które zostało wprowadzone i opisane przez K. Wojtyłę we wcześniejszych fragmentach. Sprowadza się ono do tego, że ,działanie” przypisuje on tylko tym aktom, w których człowiek jest aktywny. On jest ich autorem. „Dzianie się” natomiast przypisane jest takim rodzajem dynamizmu człowieka, w którym jest on jedynie pewnego rodzaju „miejscem akcji”, on sam natomiast pozostaje pasywny. Przykładem tego może być życie tkankowe, ale i odruchy emocjonalne. Por. tamże, 109-115.

56 Tamże, 156-157. 
dzie ten sam człowiek. Oznacza to, że przy takiej koncepcji antropologicznej właściwie należałoby mówić o „relacji samowychowawczej”, a wie - jak dotąd - o „relacji wychowawczej”. Choć może ten termin brzmi dość specyficznie, to ma on swoje uzasadnienie w antropologii nakreślonej przez Profesora KUL.

Idąc konsekwentnie za tą myślą, będzie to oznaczać, że osoba w procesie (samo)wychowania, dążąc do zachowania swojej indywidualności i podejmując bardzo aktywnie zadanie realizowania „własnego projektu życiowego", będzie reprezentowała i walczyła o to, co związane jest z kategorią ,ja chcę", wobec tego, co określane jest jako ,chce mi się”. Dla uzupełnienia i dodatkowego wyjaśnienia można przywołać tutaj pewien element herbartowskiej koncepcji wychowania. Twórca pedagogiki naukowej wskazuje na to, że w procesie kształtowania się autentycznej woli, która ma kierować życiem człowieka, obecny jest na pewnym etapie rozwoju osobowego tak zwany „niesforny pęd, bez stałego kierunku stanowiący pierwiastek nieładu, który $[\ldots]$ osobę $[\ldots]$ naraża na niebezpieczeństwo" ${ }^{57}$.

Odnosząc się do przedstawionych założeń antropologicznych, można powiedzieć, że tak rozumiana „relacja (samo)wychowawcza” będzie skłaniała do podjęcia następujących działań. Po pierwsze, będzie chodziło o rozpoznanie bądź określenie tego, co można nazwać: ,ja chcę”. Myślę, że nie zawsze jest to proste, samorzutne i intuicyjne. Bardzo często potrzeba namysłu nad wieloma doświadczeniami życiowymi, które wydawały się osobie pociaggające czy atrakcyjne, by umieć właściwie określić własne ,ja chcę”. Drugim zadaniem będzie to, by zauważyć i nazwać w swoim chceniu również aspekt „,chce mi się”. On będzie zdecydowanie bardziej intuicyjny, impulsywny, zależny od chwilowych doświadczeń, mocniej związany ze sfera afektywną oraz poddający się bardziej wpływom środowiskowym, a przez to narażony na większą możliwość zewnątrzsterowności. Nie zawsze też będzie on zgodny z tym, co osoba określiła jako ,ja chcę”. Ostatecznie zatem „relacja (samo)wychowawcza” będzie odnosiła się do działań zmierzających do zachowania i obrony własnej narracji życia w obliczu różnego rodzaju impulsów, zachcianek, które będą temu przeciwne lub sprzeczne. Tymi dwoma „podmiotami” w tak rozumianej „relacji wychowawczej” będą ,ja chcę” oraz „chce mi się”, przy czym ten pierwszy jest gwarantem autentycznego rozwoju osobowego, kreacji własnego projektu życia, a drugi często będzie widziany jako narzucający schematy zewnętrzne.

57 Jan Fryderyk Herbart, Pedagogika ogólna wywiedziona z celu wychowania (Warszawa: „Żak”, 2007), 34. 


\section{Zakończenie}

W artykule podjęto zagadnienie rozumienia „relacji wychowawczej” w zależności od wcześniej przyjętych założeń antropologicznych. Pierwszym etapem podjętych badań było określenie definicji „relacji”. Została ona opisana jako „odniesienie, którego następstwem jest sposób bytowania pomiędzy dwoma kresami" "58. Na tej podstawie stwierdzono, że zagadnieniem kluczowym dla rozumienia „relacji wychowawczej” będzie scharakteryzowanie owych „kresów”, którymi w tym przypadku będą wychowawca i wychowanek. To doprowadziło do wniosku, że na rozumienie „relacji wychowawczej" wpływa przede wszystkim teoria człowieka oraz koncepcja wychowania. Nie są to jednak faktory równoważne, ponieważ koncepcja wychowania także warunkowana jest antropologią. Stąd też w niniejszym artykule skupiono się przede wszystkim na związku pomiędzy koncepcją antropologiczną a rozumieniem ,relacji wychowawczej”.

W ostatniej części artykułu zaprezentowano wybrane koncepcje antropologiczne, ukazując zarazem ich znaczenie dla kształtowania się pola semantycznego „relacji wychowawczej”. Do podjętych koncepcji antropologicznych należą: 1. Ujęcie ewolucyjne: „Człowiek - kosmicznym rozbójnikiem”; 2. Ujęcie biologiczne: „Człowiek - fizjologicznym wcześniakiem”; 3. Ujęcie genetyczne: „Człowiek - maszyną”; 4. Ujęcie marksistowskie: „Człowiek - wytworem społecznym”; 5. Ujęcie psychoanalityczne: „Człowiek - «polem» walki nieosobowych sił" oraz 6. Ujęcie fenomenologiczne: „Człowiek - tworzący samego siebie”. Wybór poszczególnych stanowisk antropologicznych nie jest reprezentacją kompleksowego ujęcia filozofii człowieka, bo - jak pokazano powyżej - trudno o takie klasyfikacje na terenie samej filozofii, lecz w artykule przede wszystkim chciano pokazać konsekwencje dla nauki o wychowaniu konkretnych modeli antropologicznych.

Dzięki analizie terminologicznej „relacji” oraz wskazaniu na klasyczną klasyfikację bytów stwierdzono, że ten związek jest istotowy. Stąd też $\mathrm{w}$ badaniach pedagogicznych $\mathrm{w}$ przedstawionym zakresie nie można posiłkować się jedynie obszarem nauk społecznych (takich jak np. psychologia czy socjologia, dla których zagadnienie „relacji międzyludzkich” jest bardzo istotne), ale należy również odnosić się do filozofii człowieka.

58 Krąpiec, „Relacja”, 712. 


\section{Educational Relationship from the Perspective of Selected Anthropological Conceptions (Summary)}

The article is a theoretical search for the meaning of the term "educational relationship" in reference to selected anthropological assumptions. The main research problem is the question about the development of the meaning/description/definition of "educational relationship" in regard to various concepts of the human being theory. In order to answer this question, the first part presented "relationship" in general. At this stage, mostly philosophical analyses were applied. The next part showed a network of problem issues conditioning the understanding of "relationship", and the last one submitted selected anthropological conceptions and their repercussions for the understanding of "educational relationship".

Key words: concept of the human being; educational relationship; education; anthropological assumptions.

\section{Relacja wychowawcza w ujęciu wybranych koncepcji antropologicznych (Streszczenie)}

Artykuł jest teoretycznym poszukiwaniem znaczenia terminu „relacja wychowawcza" w odniesieniu do wybranych założeń antropologicznych. Podstawowym problemem badawczym jest pytanie dotyczące tego, jak kształtuje się rozumienie/ opis/definicja „relacji wychowawczej” przy różnych koncepcjach teorii człowieka. Aby odpowiedzieć na to pytanie, w pierwszym etapie zaprezentowano, czym jest „relacja” w ogóle. Na tym etapie posłużono się przede wszystkim analizami filozoficznymi. Następnie ukazano siatkę zagadnień problemowych warunkujących rozumienie „relacji”, a w ostatniej części przedstawiono wybrane koncepcje antropologiczne i ich reperkusje dla rozumienia ,relacji wychowawczej”.

Słowa kluczowe: koncepcja człowieka; relacja wychowawcza; wychowanie; założenia antropologiczne.

\section{Bibliografia}

Antropologiczna pedagogika ogólna, red. Marian Nowak, Piotr Magier, Iwona Szewczak. Lublin: Gaudium, 2010. 
Arystoteles. Polityka. Warszawa: PWN, 2010.

Burkard, Franz-Peter, Axel Weiß. Dtv-Atlas Pädagogik. München: Deutscher Taschenbuch Verlag GmbH \& Co. KG, 2008.

Cichoń, Władysław. Wartości. Człowiek. Wychowanie. Kraków: Wydawnictwo Uniwersytetu Jagiellońskiego, 1996.

Drwięga, Marek. Kim jest człowiek? Studia z filozofii człowieka. Kraków: Księgarnia Akademicka, 2013.

Gudjons, Herbert. Pädagogisches Grundwissen. Bad Heilbrunn: Klinkhardt, 2012.

Gutek, Gerald L. Filozofia dla pedagogów. Gdańsk: GWP, 2007.

Hawkes, Kristen. „Großmutter-Effekt”. W: Evolution und Kultur des Menschen, red. Ernst Peter Fischer, Klaus Wiegandt, 170-196. Frankfurt a. M.: Fischer Verlag, 2010.

Herbart, Jan Fryderyk. Pedagogika ogólna wywiedziona z celu wychowania. Warszawa: „Żak”, 2007.

Kamiński, Stanisław. „Z metafilozofii człowieka”. W: Mieczysław Albert Krąpiec, Ja-człowiek, 11-25. Lublin: Wydawnictwo KUL, 2005.

Kot, Stanisław. Historia wychowania, t. 1. Warszawa: Wydawnictwo Akademickie „Żak”, 2010.

Krąpiec, Mieczysław Albert. „Relacja”. W: Powszechna encyklopedia filozofii, red. Andrzej Maryniarczyk i in., t. 8, 712-716. Lublin: Polskie Towarzystwo Tomasza z Akwinu, 2007.

Krapiec, Mieczysław Albert. Ja-człowiek. Lublin: Wydawnictwo KUL, 2005.

Krapiec, Mieczysław Albert. Porzucić świat absurdów. Lublin: Polskie Towarzystwo Tomasza z Akwinu, 2002.

Kron, Friedriech W. Pedagogika. Kluczowe zagadnienia. Sopot: GWP, 2012.

Krüger, Heinz-Hermann. Metody badań w pedagogice. Gdańsk: GWP, 2007.

Laberthonnière, Lucien. Théorie de l'éducation. Paris, 1901.

Lévi-Strauss Claud. Mythologiques, t. 1: Lec cru et le cuit. Paris, 1964.

Marotzki, Winfried, Arnd-Michael Nohl, Wolfgang Ortlepp. Einführung in die Erziehungswissenschaft. Opladen \& Farmington Hills: Verlag Barbara Budrich, 2006.

Mączka, Janusz. „La Mettrie Julien Offrey de”. W: Powszechna encyklopedia filozofii, t. 6, red. Andrzej Maryniarczyk i in., 179-180. Lublin: Polskie Towarzystwo Tomasza z Akwinu, 2005.

Milinski, Manfred. „Egoismus schafft Gemeinsinn”. W: Evolution und Kultur des Menschen, red. Ernst Peter Fischer, Klaus Wiegandt, 270-291. Frankfurt a. M.: Fischer Verlag, 2010.

Nohl, Herman. Die pädagogische Bewegung in Deutschland und ihre Theorie. Frankfurt a. M., 1935. 
Nowak, Marian. Pedagogiczny profil nauk o wychowaniu. Studium z odniesieniami do pedagogiki pielegniarstwa. Lublin: Wydawnictwo KUL, 2012.

Nowak, Marian. Podstawy pedagogiki otwartej. Lublin: RW KUL, 1999.

Nowak, Marian. Teorie i koncepcje wychowania. Warszawa: Wydawnictwo Akademickie i Profesjonalne, 2008.

Ostrowska, Urszula. „Relacje interpersonalne w edukacji”. W: Encyklopedia pedagogiczna XXI wieku, red. Tadeusz Pilch, t. V, 179-193. Warszawa: Wydawnictwo Akademickie „Żak”, 2006.

Pedagogika. Podręcznik akademicki, red. Zbigniew Kwieciński, Bogusław Śliwerski, t. 1. Warszawa: Wydawnictwo Naukowe PWN, 2005.

Popowicz, Remigiusz. Wielki stownik grecko-polski. Warszawa: Oficyna Wydawnicza „Vocatio”, 2006.

Suchodolski, Bogdan. „Wstęp”. W: Zygmunt Freud, Człowiek - religia - kultura, 7-23. Warszawa: Książka i Wiedza, 1967.

Szacki, Jerzy. Historia myśli socjologicznej. Warszawa: Wydawnictwo Naukowe PWN, 2012.

Śliwerski, Bogusław. Wspótczesne teorie i nurty wychowania. Kraków: Impuls, 2010.

Wojtyła, Karol. „Osoba i czyn”. W: Karol Wojtyła, Osoba i czyn oraz inne studia antropologiczne, red. Tadeusz Styczeń i in., 43-344. Lublin: Towarzystwo Naukowe KUL, 2011.

Wojtyła, Karol. „Teoria - praxis: temat ogólnoludzki i chrześcijański”. W: Karol Wojtyła, Osoba i czyn oraz inne studia antropologiczne, red. Tadeusz Styczeń i in., 463-475. Lublin: Towarzystwo Naukowe KUL, 2011. 